\title{
NRADD, a novel membrane protein with a death domain involved in mediating apoptosis in response to ER stress
}

\author{
X Wang ${ }^{1}$, Z Shao ${ }^{1}$, FS Zetoune ${ }^{1}$, MG Zeidler ${ }^{1}$, K Gowrishankar $^{1}$ \\ and $C$ Vincenz ${ }^{*}, 1$ \\ 1 Department of Pathology, University of Michigan Medical School, Ann Arbor, \\ MI 48109, USA \\ * Corresponding author: Claudius Vincenz, Department of Pathology, The \\ University of Michigan Medical School, Room 7510 MSRB I, Box 0602, 1150 \\ West Medical Center Drive, Ann Arbor, MI 48109, USA. Tel.: 734647 9551; \\ Fax: 734764 4308; E-mail: vincenz@umich.edu
}

Received 17.5.02; revised 22.7.02; accepted 22.11.02

Edited by D. Nicholson

\begin{abstract}
NRADD (neurotrophin receptor alike death domain protein) is a novel protein with transmembrane and cytoplasmic regions highly homologous to death receptors, particularly p $75^{\mathrm{NTR}}$. However, the short $\mathrm{N}$-terminal domain is unique. Expression of NRADD induced apoptosis in a number of cell lines. The apoptotic mechanism involved the activation of caspase-8 and execution of apoptosis without requiring mitochondrial components. The activation of this death receptor-like mechanism required the $\mathrm{N}$-terminal domain, which is $\mathrm{N}$ glycosylated and needed for subcellular targeting. Deletion of the $\mathrm{N}$-terminal domain produced a dominant-negative form of NRADD that protected neurons and Schwann cells from a variety of endoplasmic reticulum (ER) stressors. NRADD may therefore be a necessary component for generating an ERinduced proapoptotic signal.

Cell Death and Differentiation (2003) 10, 580-591. doi:10.1038/ sj.cdd. 4401208
\end{abstract}

Keywords: death receptors; apoptosis; caspases; endoplasmatic reticulum

Abbreviations: NRADD, Neurotrophin receptor alike death domain protein; ER, Endoplasmic reticulum; DD, Death domain; PI, Propidium iodide; FL, Full length; GFP, Green fluorescent protein; RFP, Red fluorescent protein; ER-YFP, ER-targeted yellow fluorescent protein.

\section{Introduction}

Since the discovery of the homology between the death promoting Caenorhabditis elegans gene Ced3 and the interleukin-1 $\beta$-converting enzyme (caspase-1), numerous mammalian gene products involved in apoptosis have been identified based via homology. ${ }^{1}$ Prevalent among these are proteins containing domains belonging to the death domain (DD) superfamily. This superfamily is defined by its conserved tertiary structure and consists of the DD, the caspase recruitment domain (CARD), and the death effector domain (DED) families of proteins. ${ }^{2}$ The function of these domains is to mediate homotypic interactions between specific members of each family. The pyrin domain, for which a structure has not been solved yet, functions in a similar manner and has been

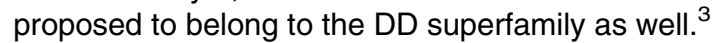

Death receptors are transmembrane proteins belonging to the TNFR/NGFR superfamily that contain a DD in their cytoplasmic tail. ${ }^{4}$ They are activated by the binding of their cognate ligands to the extracellular domain. Activation of death receptors can induce apoptosis as in the case of Fas or the pleiotropic responses observed with TNFR1. The mechanism by which apoptosis is induced by death receptors is surprisingly direct. The adaptor molecule FADD is sufficient to transmit the signal from death receptors to the apical caspase8 and 10. In some cell types cleavage of BID by caspase- 8 is required to enhance the signal via mitochondrial components. JNK and NF- $\kappa$ B pathways are nonapoptotic signaling cascades activated by death receptors. Proximally, these pathways use the same receptor signaling molecules, as do apoptotic pathways, but different adaptor molecules are engaged distally.

The $\mathrm{p} 75^{\mathrm{NTR}}$ death receptor is particularly complex because it physically and functionally interacts with the Trk neurotrophin receptors. Therefore, its proapoptotic activity is often masked or even reversed. In addition, p75 ${ }^{\mathrm{NTR}}$ binds with lowaffinity neurotrophins, which do not belong to the TNF ligand family. ${ }^{5}$ Recently, proneurotrophins have been identified as the high-affinity proapoptotic ligands for $p 75^{\text {NTR }} 6$ Apoptotic signaling from $\mathrm{p} 75^{\mathrm{NTR}}$ has several steps in common with signaling from other death receptors, but the receptor proximal adaptor molecules are different. ${ }^{7}$ Intriguingly, despite extensive efforts no homotypic interaction partner for the p75 ${ }^{\text {NTR }}$ DD has been identified. A plethora of molecules mediating $\mathrm{p} 75^{\mathrm{NTR}}$ signal transduction have been identified mainly on the basis of protein-protein interactions. ${ }^{5}$ Their precise involvement in the multiple signals that emanate from p75 ${ }^{\mathrm{NTR}}$ remains to be elucidated.

Death receptors permit the cell to receive proapoptotic signals from the extracellular milieu. However, apoptosis is also a frequent cellular response to insults that affect intracellular components. For example, apoptosis induced by stressors of the endoplasmic reticulum (ER) is thought to involve activation of ER-membrane components by luminal proteins. ${ }^{8}$ Ire 1 and PERK are ER-associated kinases containing conserved luminal domains. ER chaperones, specifically GRP proteins like BiP/GRP78, are thought to bind these domains and keep them in an inactive state. ${ }^{9}$ Induction of $\mathrm{BiP} /$ GRP78 is a protective response and confers resistance to ER stressors. The same kinases also induce the activation of the JNK pathway using similar adaptor molecules as the death 
receptors. ${ }^{10}$ Whether JNK activation by ER stressors is pro- or antiapoptotic is not fully understood. Activation of caspase-12 is the best understood molecular event of the proapoptotic signals emanating from the ER. ${ }^{11}$ Calpain, Traf2, and caspase-7 have all been proposed to activate caspase$12 .^{12-14}$ It is unclear how these upstream mediators communicate with ER components and whether they are each activated by a subset of ER death stimuli or if they act in concert. The Ire kinases induce apoptosis at least in part by inducing the transcriptional factor $\mathrm{CHOP}^{15}$ As $\mathrm{CHOP}-1-$ mice show only a modest reduction in cell death, additional proapoptotic pathways are probable.

Here we describe the molecular cloning and characterization of a new molecule with homology to the intracellular domain of $\mathrm{p} 75^{\mathrm{NTR}}$. This type III transmembrane protein, termed neurotrophin receptor alike death domain protein (NRADD), is widely expressed during development and in adult tissues. NRADD expression induces apoptosis using an apoptotic pathway similar to the one used by death receptors.
The N-terminal domain has an $\mathrm{N}$-glycosylation consensus site and is necessary for the induction of apoptosis. A dominantnegative form of NRADD inhibits apoptosis induced by several stressors of the ER. This inhibition is observed in immortalized neurons as well as Schwann cells, suggesting that NRADD may mediate ER stress-induced apoptosis.

\section{Results}

EST databases were searched for DD superfamily proteins to identify new molecules potentially involved in apoptosis. Using the DD of $p 75^{\mathrm{NTR}}$ as the search query, a new DDcontaining protein was discovered and the full-length (FL) sequence was obtained from an embryonic mouse library. An in-frame upstream stop codon confirmed that the sequence was indeed FL. The stop codon was also present in several other mammalian sequences assembled from ESTs (Figure 1a). The human cDNA was assembled from the contig

a

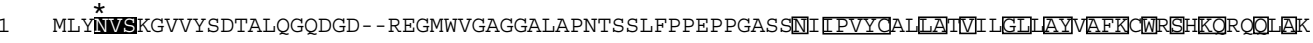

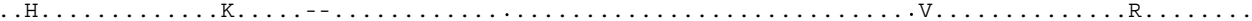

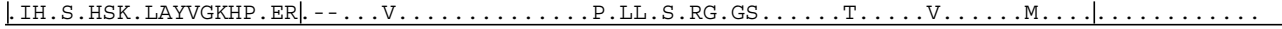

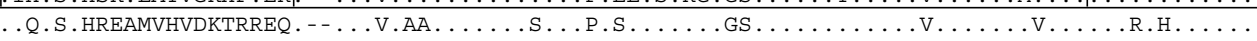

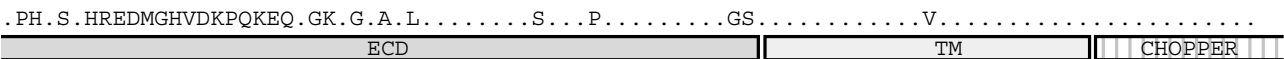

mus musculus rattus norvegicus homo sapiens bos taurus sus scorfa

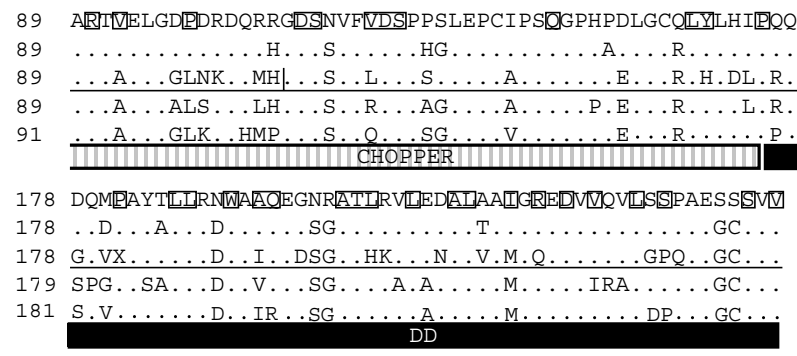

b

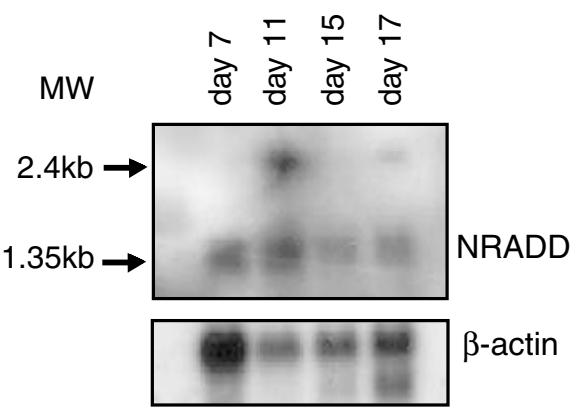

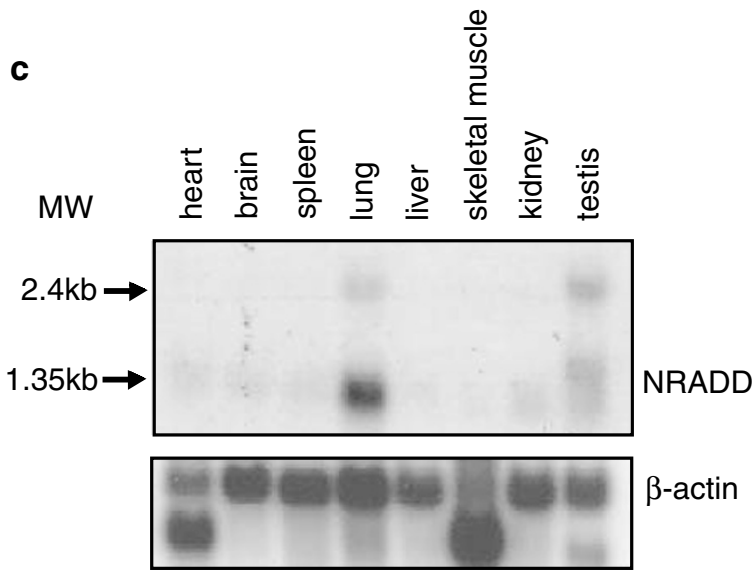

Figure 1 Sequence and expression analysis of NRADD. (a) The NRADD sequences of five mammals were assembled and aligned. Identical amino acids are indicated by dots. The mouse sequence was obtained from an embryonic cDNA library. The rat sequence was obtained by RT-PCR from ST14A cells. The human sequence was assembled from genomic data and the sequence from other species by assembling ESTs. Amino acids that are identical between mNRADD and mp75 ${ }^{\mathrm{NTR}}$ are boxed. The Asn and the conserved N-glycosylation consensus is marked $\left(^{*}\right)$ and boxed in black, respectively. The putative domains are indicated by the bars. ECD: ecto domain; TM: transmembrane domain; CHOPPER: chopper domain; DD: death domain. The putative intron boundaries are indicated by vertical bars in the human sequence. (b, $\mathbf{c})$ Northern blot of staged mouse embryos and of mRNA from tissues of adult mice. Blots are probed with NRADD and $\beta$-actin as indicated 
on 3p21. Two exons encode the $\mathrm{N}$-terminal and putative transmembrane domains. The putative intracellular domain consists of two more exons with similar boundaries to those of p $75^{\mathrm{NTR}}$, suggesting that the two genes were derived from the same progenitor by exon shuffling. The mammalian sequences show a high degree of conservation except for the $18 \mathrm{~N}$-terminal amino acids encoded by the first exon. However, an $\mathrm{N}$-glycosylation consensus site remains conserved at Asn4.

This new protein has extensive homology not only to the DD of $\mathrm{p} 75^{\mathrm{NTR}}(54 \%)$, but also to the juxtamembrane domain $(55 \%)$ and the transmembrane domain $(88 \%)$ of $p 75^{\text {NTR }}$. Based on these sequence comparisons the molecule was named NRADD. However, the short $\mathrm{N}$-terminal domain of NRADD lacks any homology to the extracellular domain of p75 ${ }^{\text {NTR }}$ or any other TNFR/NGFR superfamily member. The signal peptide sequence found in all other death receptors is not present in NRADD. Analysis of the DD sequence of NRADD revealed that all the amino acids constituting the hydrophobic core are conserved, which suggests a secondary structure consisting of the same six $\alpha$-helices as found in the other DDs (not shown). The NRADD's DD is most similar to that of $p 75^{\mathrm{NTR}}$ with $44 \%$ identity and shares about $20 \%$ of the amino acids with other death receptors. The DD of FAS and TNFR1 are the least related with $\sim 13 \%$ identity.

\section{NRADD is widely expressed during development and in adult tissues}

Northern blot analysis of RNA isolated during different stages of development and adult tissues revealed NRADD mRNA of two sizes $(\sim 2.4$ and $\sim 1.4 \mathrm{~kb}$, Figure $1 \mathrm{~b})$. Both forms are expressed throughout development. In most adult tissues expression is weaker and only the lower band is discernible (Figure 1c). Both RNA sizes are detected in lung and testis where expression is high. NRADD expression was also assayed qualitatively by RT-PCR in all cell lines used in this study. Only the embryonic kidney epithelial cell line 293 was negative for NRADD expression (not shown). A similar, but not identical, broad expression pattern is also observed for p75 ${ }^{\text {NTR }}$. For example, ST14A cells used in this study do not express $\mathrm{p} 75^{\mathrm{NTR}}$, but do express NRADD. ${ }^{7}$

\section{NRADD induces apoptosis in a subset of cells}

DD containing molecules are frequently involved in transmitting apoptotic signals and expression of these proteins will trigger cell death. To ascertain whether NRADD has proapoptotic activity, constructs expressing FL-NRADD were transiently transfected into a panel of cell lines and the propidium iodide $(\mathrm{PI})$ staining pattern of the transfected cells was evaluated $48 \mathrm{~h}$ later (Figure $2 \mathrm{a}$ ). In the parental striatal cell line, ST14A, about $15 \%$ of NRADD transfected cells were scored as apoptotic, which is significantly higher than in cells transfected with the GFP control (5\%). The extent of killing increased with the amount of transfected NRADD (inset).

NRADD was also assayed in ST14A cells stably transfected with a ponasterone-inducible $\mathrm{p} 75^{\mathrm{NTR}}$ construct to investigate a potential synergy between these homologous proteins. ${ }^{7}$
NRADD-induced cell death in this line was similar to that observed in the parental line. Combining the p $75^{\mathrm{NTR}}$ apoptotic stimulus, by adding ponasterone, with NRADD transfection produced $\sim 40 \%$ killing in the transfected cells. Although this is clearly higher than with either stimulus alone, the effect is only additive and not synergistic.

Expression of NRADD also induced cell death in neuroblastoma lines SHEP and SHSY5Y. Furthermore, primary Schwann cells isolated from rat embryos were the most susceptible to NRADD killing. No significant cell death was observed in PC12, 293, and MCF7 cells. NIH3T3 and HeLa cells were also resistant to NRADD killing (not shown). These results indicate that NRADD is moderately proapoptotic in several cell types, but not in other cells that have been shown to be susceptible to death receptor killing.

ST14A lines stably transfected with NRADD were generated to study NRADD-induced cell death in more detail. FLAG-tagged NRADD was expressed under the control of ecdysone promoter, so that expression of the protein is induced by the addition of ponasterone. The level of protein expression was measured by Western blotting (Figure 2b). Three classes of clones were obtained: (i) clones represented by 4 and 9 , which show no expression in the absence of ponasterone and good inducibility, (ii) clones with poor induction and NRADD expression in the absence of ponasterone (clone 8), and (iii) clones with no expression even after induction (clone 5). The extent of cell death was measured by comparing the viability of ponasterone-treated cells with the untreated controls (Figure 2c). Ponasterone killed more than $70 \%$ of the cells during a $48 \mathrm{~h}$ exposure in the clones with inducible NRADD expression. No change in viability was seen in the nonexpressing clone 5, which was similar to the vector control. NRADD stable lines were also generated in MCF7 and NIH3T3 cells. Induction of NRADD was not cytotoxic in these cells, confirming the cell-type specificity observed in the transient transfection assays (not shown). NRADD mRNA levels were measured in stably transfected and parental ST14A cells to determine whether the strong proapoptotic activity observed in the inducible stable lines was because of gross overexpression. Northern blot analysis revealed only about a two-fold increase of NRADD in the stable transfectants (Figure 2d), suggesting comparable levels of exogenous and endogenous NRADD.

The cells killed by ponasterone displayed the apoptotic morphology of shrunken rounded cells with membrane blebs (not shown). To ascertain at a molecular level that cell death proceeded by an apoptotic mechanism, DNA from NRADDexpressing cells was compared to the noninduced control (Figure 2e). NRADD expression induced a DNA ladder pattern of $\sim 200 \mathrm{bp}$ periodicity characteristic of cells undergoing apoptosis.

\section{NRADD signals apoptosis similar to death receptors}

Caspase activity was measured in lysates from cells undergoing NRADD-induced apoptosis (Figure 3a). Caspasespecific substrates were used in order to distinguish between different subgroups. Significant caspase-3-like (DEVD) activ- 


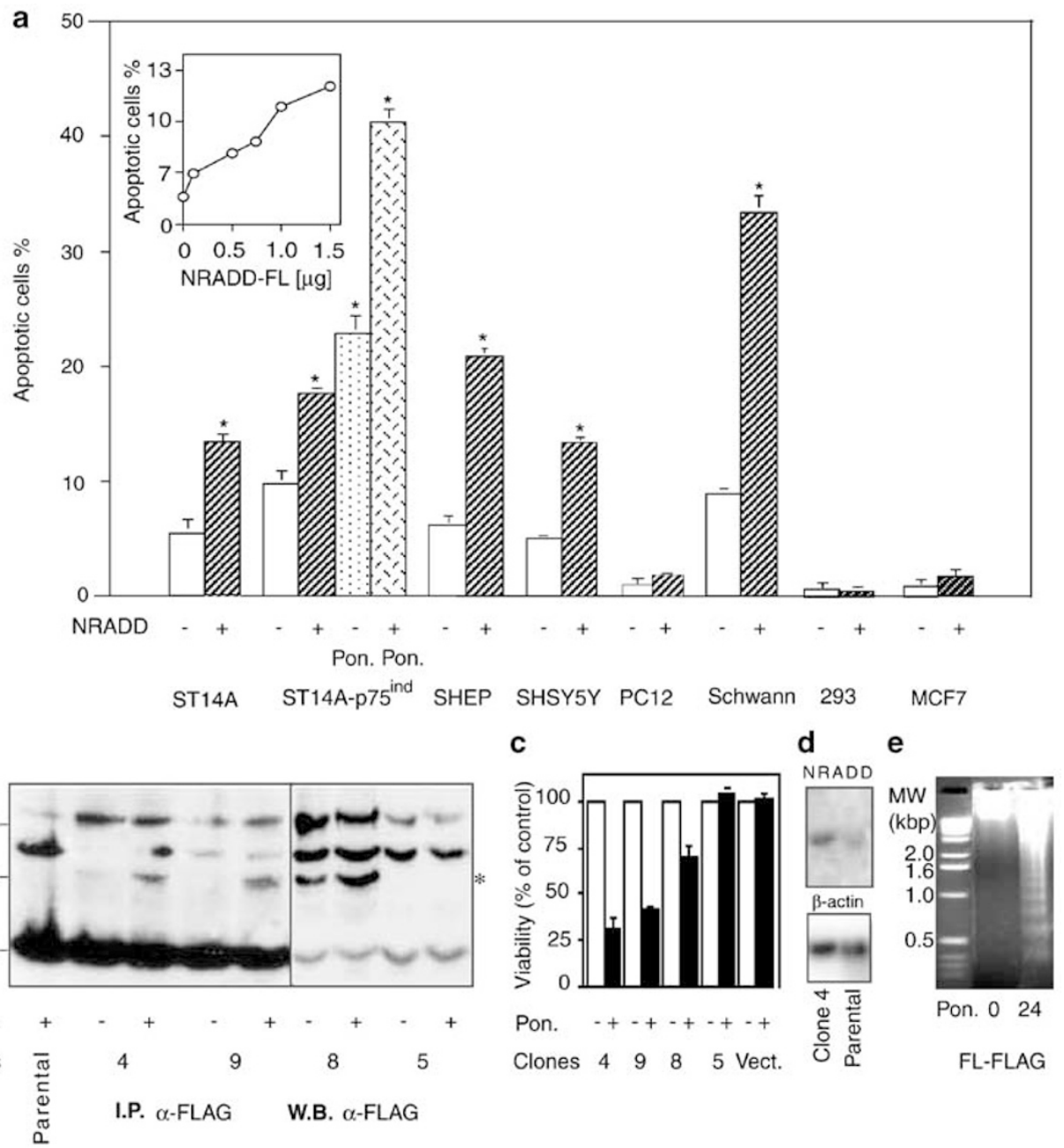

Figure 2 Expression of NRADD induces apoptosis in multiple cell lines. (a) The indicated cell lines were cotransfected with $1 \mu \mathrm{g}$ of FL-NRADD (striped bars) or vector and GFP (white bars) for $48 \mathrm{~h}$. ST14A-p75 ${ }^{\text {ind }}$ express p $75^{\mathrm{NTR}}$ upon ponasterone addition. ${ }^{7}$ Transfected cells were stained with PI and scored by fluorescence microscopy. Inset shows a dose-response curve of NRADD killing in ST14A cells. The values are mean \pm S.E. of six independent experiments for ST14A cells ( $n=6$ ) (for other cell lines $n>3$ ). Significant killing by NRADD is indicated $\left({ }^{*}, P<0.05\right)$. (b) Several clones of ST14A stably transfected with FL-FLAG-NRADD in the ecdysone inducible vector were treated with ponasterone for $48 \mathrm{~h}$. Expression of the FLAG-tagged constructs was assayed by FLAG immunoprecipitation (I.P.) and Western blot (W.B.). L.C.: light chain. * indicates NRADD bands. (c) Cell viability was measured by MTS assay after $48 \mathrm{~h}$ of ponasterone treatment (filled bars) or untreated controls (white bars). (d) Northern blot of mRNA isolated from parental and clone 4. (e) DNA was extracted from an equal number of transfectants treated with ponasterone for the indicated times, and analyzed by agarose gel electrophoresis (one of three experiments shown)

ity was induced consistent with the induction of the apoptotic effector machinery. Of the apical caspases tested in this assay, only caspase-8-like activity (IETD) increased significantly. Caspase-1-like activity (YVAD) did not increase at all and only an insignificant increase in caspase-9-like activity (LEHD) was detected. This caspase activation pattern is reminiscent of death receptor signaling in cells, which do not require a mitochondrial amplification loop. Furthermore, addition of BAF, a broad-range caspase inhibitor, inhibited NRADD-induced cell death. NRADD therefore requires caspase activation to induce apoptosis. We also assayed the activation status of caspase-12, another apical caspase, by Western blot analysis. Induction of NRADD by ponasterone resulted in the cleavage of caspase-12, a common indicator of its activation (Figure $3 b$ ). ${ }^{11}$ The same cleavage products were also induced by treatment with the ER stressor brefeldin A. Caspase-12 was not processed in this cell line by the DNA damaging agent etoposide. A NRADD-specific response is also indicated by the lack of caspase-12 processing by ponasterone treatment in the vector control line (not shown). Thus, NRADD expression leads also to activation of caspase-12, a caspase implicated in ERmediated apoptosis.

To further map which apoptotic pathways are activated by NRADD, apoptotic inhibitors with specific targets were employed (Figure 3c). Cell death was induced in ST14A by transfection with FL-NRADD. Upon cotransfection of the various inhibitors, differing degrees of protection were observed. The VFLIP proteins E8 and MC159 decreased the amount of apoptosis to background levels. The caspase inhibitors CrmA and p35 also conferred significant protection. In contrast, $\mathrm{Bcl}-\mathrm{x}_{\mathrm{L}}$, a potent inhibitor of multiple death 
a

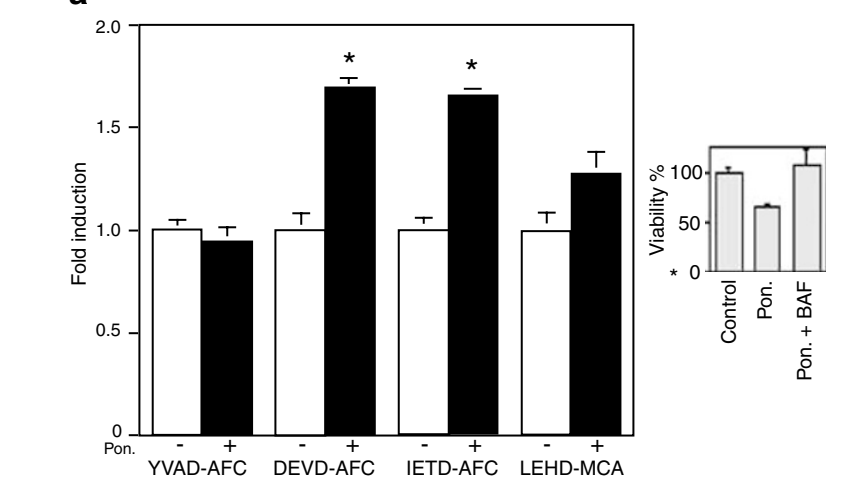

b

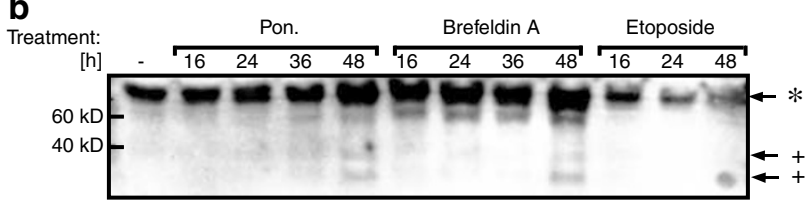

C

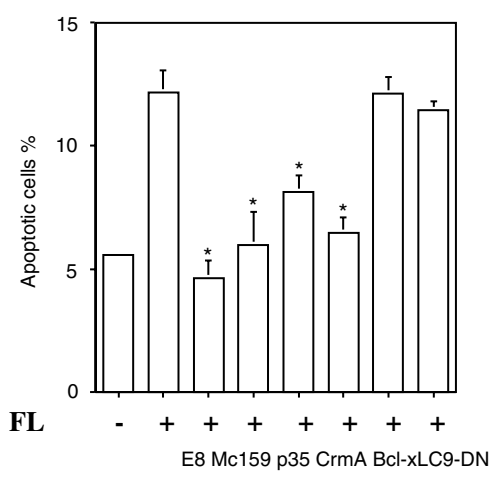

Figure 3 Characterization of the NRADD apoptotic pathway. (a) Approximately $5 \times 10^{6} \mathrm{FL}-\mathrm{NRADD}$ ST14A transfectants were treated with $15 \mu \mathrm{M}$ ponasterone for $48 \mathrm{~h}$. Caspase activity in the cell lysates was measured as described in Materials and Methods. The values are mean \pm S.E. of three independent experiments $(n=3)$. Significant increase of caspase activity is indicated $\left({ }^{*}\right.$, $P<0.05)$. The viability was measured by MTS assay after $24 \mathrm{~h}$ treatment with ponasterone in presence or absence of $50 \mu \mathrm{M}$ of the PAN caspase inhibitor BAF. (b) FL-NRADD ST14A transfectants were treated as indicated for various periods followed by lysis and Western blot analysis with $\alpha$-caspase- 12 antibodies. Fulllength $\left({ }^{*}\right)$ and processed caspase-12 bands are indicated $(+)$. (c) ST14A cells were cotransfected with NRADD-FL and GFP plus a plasmid expressing the indicated inhibitor. After $48 \mathrm{~h}$, the nuclei were stained with $\mathrm{PI}$ and the staining pattern of transfected cells was evaluated by fluorescence microscopy. The number of transfected cells with apoptotic PI staining over the number of total counted GFP-positive cells is given $(n=3)$. The values are mean \pm S.E. of three determinations. Significant inhibition compared to transfection with FL-NRADD alone is indicated $\left.{ }^{*}, P<0.05\right)$

pathways that involve release of proapoptogenic factors from mitochondria, did not have any effect. Similarly, caspase-9 dominant negative, an inhibitor of apoptosome activation, was also inactive. Bcl- $x_{L}$ and caspase-9 DN were functional in ST14A cells as evidenced by their ability to inhibit the p75 ${ }^{\text {NTR }}$ proapoptotic signal. ${ }^{7}$ This inhibitor profile suggests that NRADD induces apoptosis by a mechanism that does not require factors released from the mitochondria nor the subsequent effector complex, the apoptosome.

\section{Induction of apoptosis by NRADD requires the $\mathrm{N}$-terminal domain}

Deletion mutants were tested to identify which domains of NRADD are necessary for generating a proapoptotic signal (Figure 4A, B). Expression of the FL-NRADD constructs induced apoptosis within $48 \mathrm{~h}$ in $20-25 \%$ of SHEP cells and in more than $30 \%$ of Schwann cells. Deletion of the ecto-domain (ECD) completely inactivated NRADD. Furthermore, the putative intracellular domain (ICD) or the DD alone was similarly inactive. NRADD without a death domain $(\triangle D D)$ retains significant proapoptotic activity, particularly in Schwann cells. This mutational analysis indicated that the ECD is the strongest determinant of NRADD's apoptotic activity. The extracellular domain of $p 75^{\mathrm{NTR}}$ was replaced with the ECD of NRADD to find out if this activity was autonomous and could elicit similar effects on other transmembrane proteins. Deletion of the extracellular domain of $p 75^{\text {NTR }}$ eliminated the proapoptotic activity as reported previously in cellular systems. ${ }^{16}$ Fusion of the ECD of NRADD recovered half of the apoptotic activity observed with the wild type (wt)$p 75^{\text {NTR }}$. Therefore, the short ECD is required for the proapoptotic activity of NRADD and it can function in a heterologous context of other proapoptotic transmembrane proteins.

\section{NRADD is a type III transmembrane protein}

To monitor the intracellular distribution of NRADD, C-terminal GFP and N-terminal FLAG constructs were expressed in ST14A and 293 cells, respectively (Figure 4C). FL-NRADD autofluorescence was detectable in the perinuclear region $8 \mathrm{~h}$ after transfection (a). Cotransfection of an ER-targeted yellow fluorescent protein (ER-YFP) with the red-tagged NRADD (RFP) revealed a high degree of colocalization (c). On the other hand, mitotracker stain did not colocalize with NRADD (b), suggesting that NRADD is retained initially in the ER prior to transport to the cell membrane, typical for transmembrane proteins. After $24 \mathrm{~h}$, NRADD-GFP fluorescence was distributed throughout the cell and accumulated nonuniformly at the cell surface and in cell extensions (d). Neither mitotracker nor ER marker colocalized significantly with NRADD $24 \mathrm{~h}$, posttransfection. To further confirm that NRADD was expressed on the cell surface, 293 cells were transfected with N-terminal AU1-tagged NRADD (f). Subsequent FACS analysis was performed using $\alpha$-AU1 antibodies without permeabilization. The specific AU1 signal indicates a surface exposed $\mathrm{N}$ terminus and is consistent with NRADD being a type III transmembrane protein. This FACS analysis was also performed with FLAG-tagged NRADD yielding the same result (not shown). Penetration of the $\mathrm{N}$-terminus through a lipid bilayer is also predicted by the positive-inside rule. ${ }^{17}$ Six positively charged amino acids are located on the C-terminal side of the putative TM domain and none on the $\mathrm{N}$-terminal side.

C-terminal GFP fusions of wt NRADD and deletion mutants were transfected into ST14A cells to further characterize the determinants for subcellular localization $(g-0)$. Cellular membranes were stained with the lipophilic dye DiD (h, k, n) $24 \mathrm{~h}$ after transfection. Comparison of the FL-NRADD 
A

$$
\begin{array}{r}
\text { FL-Myc } \\
\text { FL-FLAG } \\
\text { FL-GFP } \\
\Delta E C D-F L A G \\
\text { ICD-GFP } \\
\text { DD } \\
\Delta D D \\
\text { ECD }^{\text {NRADD }}-\mathrm{p} 75 \Delta E C D \\
p 75 \Delta E C D \\
p 75
\end{array}
$$
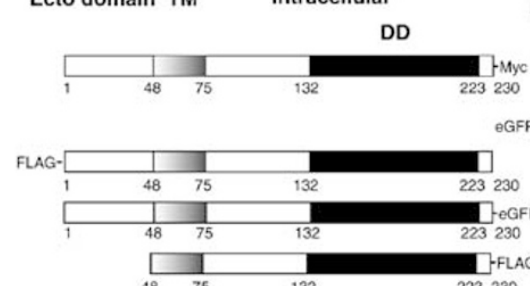

DD

$\triangle E C D-R F P$

ECD/TM-GFP
B

Apoptotic cells \%

\section{NRADD-GFP NRADD-GFP + Mitotracker ER-YFP + NRADD-RFP}
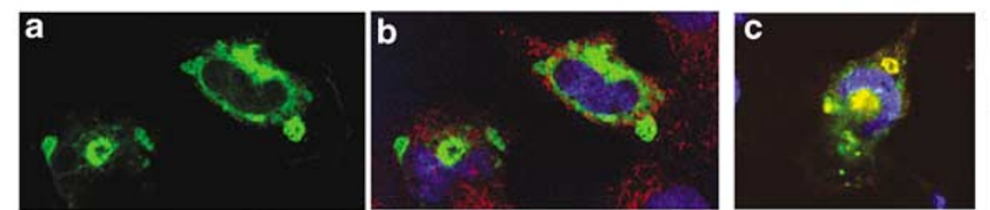

$8 \mathrm{~h}$
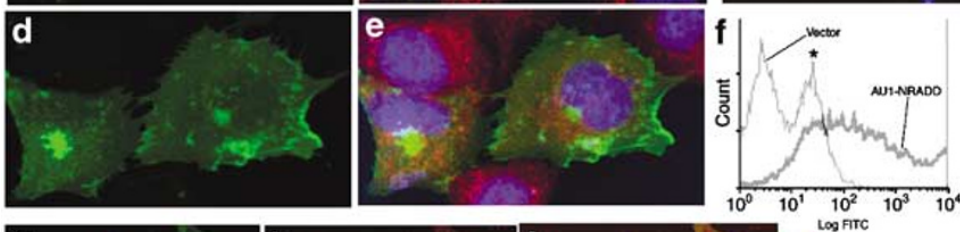

$24 \mathrm{~h}$
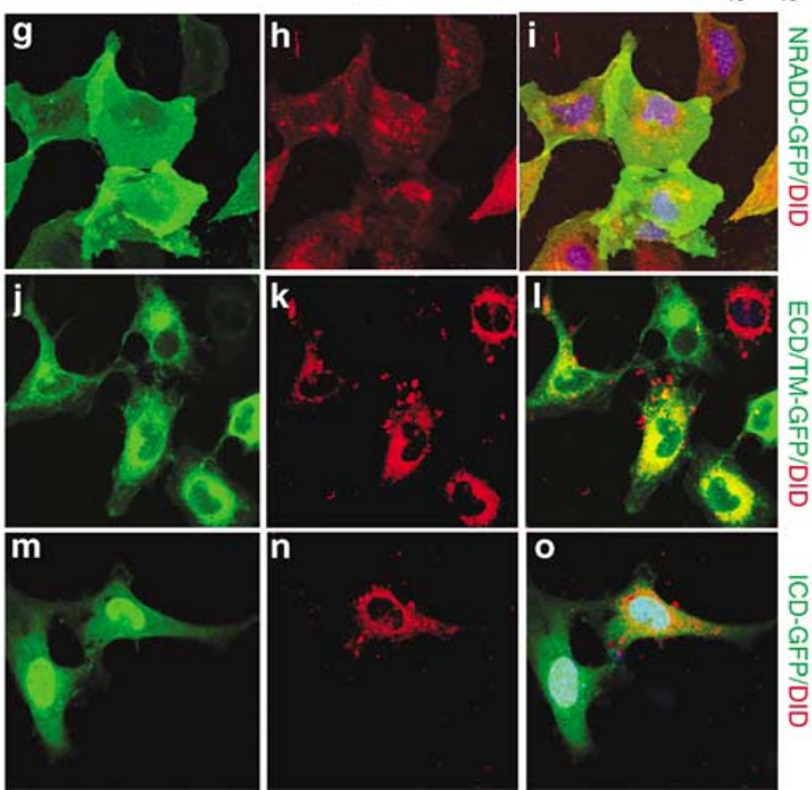

Figure 4 The N-terminal domain is a major determinant for cellular localization and proapoptotic activity of NRADD. (A) Diagram and nomenclature of NRADD constructs used in this study are shown. (B) SHEP and Schwann cells were transfected with indicated constructs with or without GFP. Cells were scored for apoptotic morphology by fluorescence microscopy. The results are from three experiments $(n=3)$. (C) ST14A cells were transfected with NRADD-GFP or RFP constructs and colocalization with mitochondria (b, e) or ER (c) was determined (colocalization is in yellow). Nuclei were stained with DAPI (blue). The FACS analysis was performed in 293 cells after transfection with AU1-NRADD or vector without permeabilization using $\alpha$-AU1 antibodies (f). * indicates background staining of the AU1 antibody. Membrane localization of FL and NRADD deletion mutants was assayed with the lipophylic dye DiD $24 \mathrm{~h}$ after transfection $(\mathrm{h}, \mathrm{k}, \mathrm{n})$. Note that DiD is cell permeable and also stains the intracellular membranes, colocalization is in yellow in the combined micrographs $(\mathrm{i}, \mathrm{l}, \mathrm{0})$ 
fluorescence with DiD fluorescence demonstrates the enrichment of NRADD in the cell membrane versus intracellular membranes (i). Expression of a construct containing the ECD and the putative TM domains fused to GFP resulted in a very different localization pattern (j). The bulk of the fluorescence colocalized with the DiD stain around intracellular membranes surrounding the nucleus (I). The construct containing only the intracellular domain distributed evenly in the cytoplasm and was enriched in the nucleus $(\mathrm{m})$. No colocalization with the DiD stain was apparent $(n, 0)$. This distribution was indistinguishable from GFP alone (not shown). While these results clearly reveal that the ECD and the putative TM domains are required for membrane localization, they also show that the putative ICD contributes to direct NRADD to the cell membrane.

\section{NRADD is N-glycosylated}

The predicted molecular weight of NRADD is $25 \mathrm{kDa}$. Expression of NRADD, however, yields a band of $\sim 37 \mathrm{kDa}$. The mouse amino-acid sequence contains the $\mathrm{N}$-glycosylation consensus site (NXS/T) at N4 and N37 (Figure 1). The N4 site is conserved in all species, while N37 is not found in the bovine and pig sequences. These putative sites were mutated and the resulting constructs expressed in 293 cells to investigate whether NRADD is glycosylated (Figure 5). Expressions were also performed in the presence of tunicamycin, an inhibitor of $\mathrm{N}$-glycosylation. FL-NRADD yielded the largest molecular weight band while the single mutants were of intermediate size. All constructs had the same fastest mobility in the presence of tunicamycin. The double mutant N4Q/N37Q expressed poorly and only a weak band comigrating with tunicamycin-treated NRADD was detectable. Low expression of $\mathrm{N} 4 \mathrm{Q} / \mathrm{N} 37 \mathrm{Q}$ is probably because of proteolysis as indicated by the accumulation of smaller bands.

To confirm the mutational analysis, FLAG-NRADD was expressed in 293 cells, purified by immunoprecipitation and deglycosylated in vitro by PNGase F (Figure $5 b$ ). The same reduction in size was obtained by $P N G$ ase $F$ treatment as by expression in the presence of tunicamycin. Inhibition of $\mathrm{N}$ glycosylation had no effect on the $\triangle E C D$ construct, indicating that the only sites N-glycosylated on NRADD are N4 and N37 on the ECD.

The localization of NRADD-GFP expressed in the presence of tunicamycin was determined (Figure $5 \mathrm{c}$ ). The nonglycosylated NRADD accumulated in the perinuclear regions, similar to the ER localization observed $8 \mathrm{~h}$ after transfection (Figure $4 c)$. This retention in the ER is similar to that seen with other $N$ glycosylated proteins. ${ }^{18}$ Deletion of the ECD also leads to retention in the ER (Figure $7 b$ ).

wt NRADD-myc was poorly expressed and addition of tunicamycin increased the expression of wt NRADD to the level of the point mutants (Figure 5a). Treatment with tunicamycin does not normally lead to increased expression levels of transfected proteins. Moreover, glycosylated NRADD is susceptible to degradation as evidenced by the degradation products seen with NRADD tagged with myc at the C-terminus but not with the FLAG epitope placed on the N-

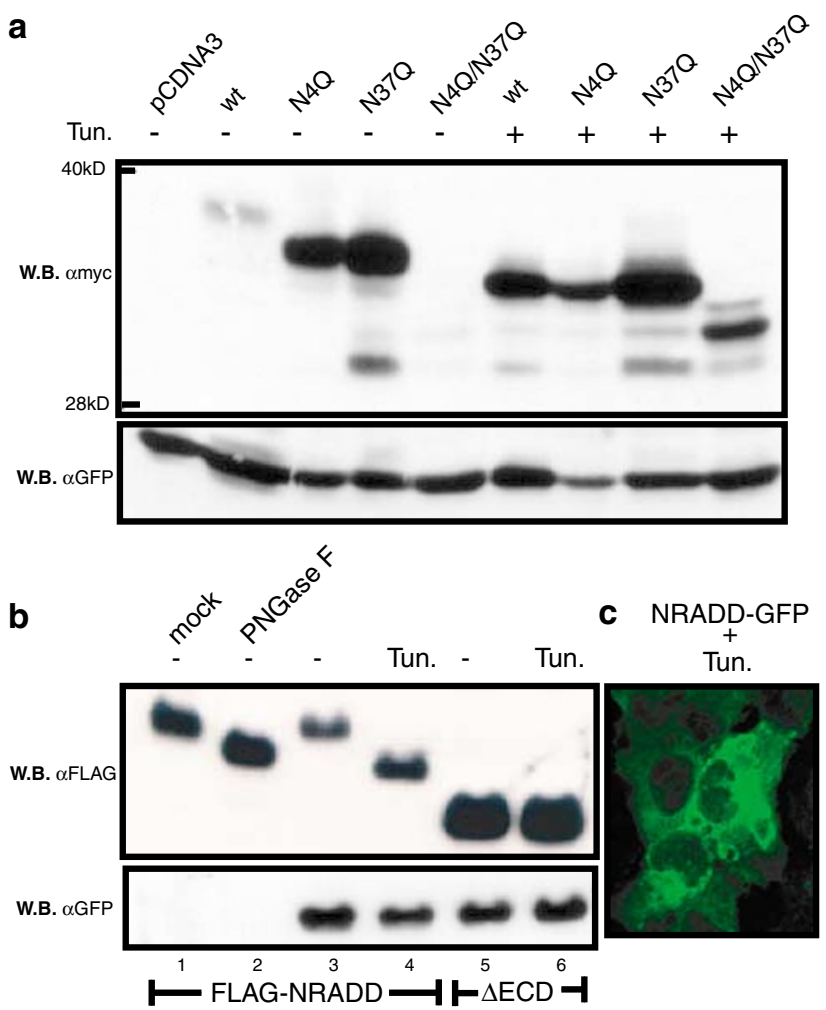

Figure 5 NRADD is N-glycosylated. (a) the 293 cells were cotransfected with the indicated constructs and GFP. Tunicamycin $(5 \mu \mathrm{g} / \mathrm{ml})$ was added $6 \mathrm{~h}$ after transfection for $12 \mathrm{~h}$ prior to cell lysis and Western blot analysis. (b) The 293 lysates were immunoprecipitated with FLAG beads and deglycosylated in vitro by mock or PNGase $F$ treatment (lanes 1 and 2). The size of the products was compared to FL NRADD or $\triangle E C D$ produced in the presence or absence of tunicamycin. (c) ST14A cells transfected with NRADD-GFP were treated with tunicamycin and visualized by confocal microscopy. Note the perinuclear fluorescence similar to (a) in Figure $4 \mathrm{C}$

terminus. Modification of the N-terminus by the FLAG tag also stabilizes NRADD (Figure 5b). These observations suggest that modifications of the ECD by glycosylation or by epitope tags affect NRADD stability.

\section{NRADD activates the JNK pathway}

Transmembrane proteins with DDs often activate multiple signaling pathways in addition to caspases. Luciferase reporter assays were performed to address whether NRADD has also the potential to trigger multiple intracellular signals (Figure 6). Transfection of NRADD induced a robust induction of an AP-1 reporter construct in a dose-dependent manner in ST14A cells (Figure 6a). The maximum level of induction was comparable to MEKK1, a known inducer of this pathway. The AP-1 promoter is controlled not only by JNK activation but other signaling pathways as well. An ATF2-GAL4 fusion protein provided a more specific read-out. ATF2 is a substrate for the p38 kinase and the activity of a GAL4 promoter yields a measure of activation of the p38 pathway. Cotransfection of NRADD with the ATF2 reporter system produced a four-fold induction of luciferase in a dose-dependent manner (Figure $6 b)$. CHOP (GADD153) is also a transcription factor that is a 
a

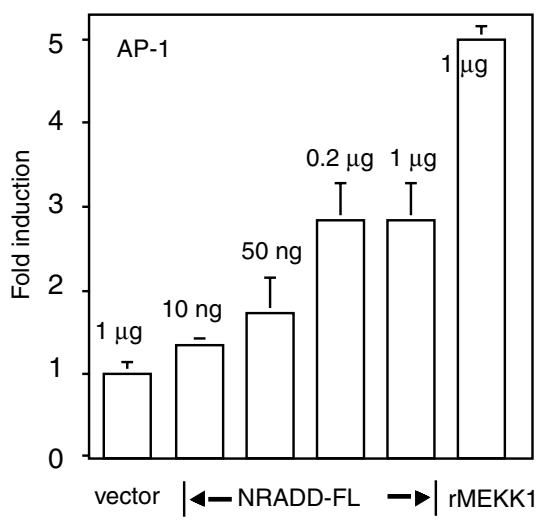

b

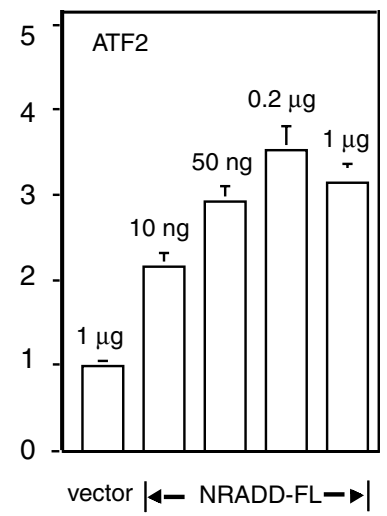

C

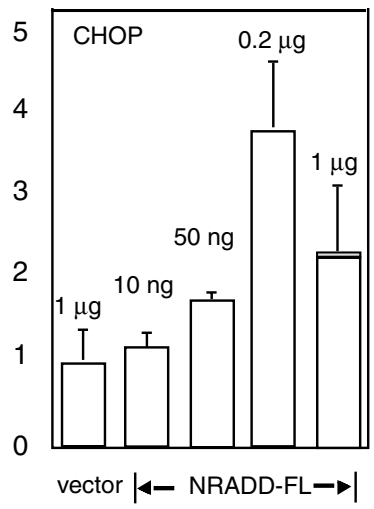

Figure 6 NRADD activates multiple signaling pathways. (a) ST14A cells were transfected with the indicated constructs and a luciferase gene driven by the AP-1 promoter. Luciferase activities were normalized for transfection efficiency and compared to the vector control as outlined in Materials and Methods. (b) ATF2 transactivation activity was measured in ST14A cells using an ATF-2-GAL4 fusion protein and a GAL4 promoter-driven luciferase construct (trans-reporting system from Stratagene). (c) Same as in B using the trans-reporting system for CHOP. Mean values \pm S.E. of three experiments are shown $(n=3)$

substrate for p38 and promotes cell death induced by ER stress. ${ }^{15,19}$ A GAL4-CHOP fusion protein was used to measure the induction of its transactivation activity by NRADD (Figure 6c). A similar dose-response curve as with ATF2 was observed. This survey therefore indicates that NRADD has the potential to activate multiple kinase cascades possibly affecting other cellular functions in addition to apoptosis.

\section{ER-mediated apoptosis is inhibited by NRADD dominant negative}

To obtain insight into the physiological function of NRADD, deletion mutants were screened for a dominant negative effect on the proapoptotic activity of FL-NRADD. ST14A cells stably expressing FL-NRADD in the ecdysone system were transiently transfected with vector or the potential inhibitors (Figure 7a). Expression of $\triangle \mathrm{ECD}$ eliminated almost all the proapoptotic activity of NRADD. The inhibition was similar to that observed with E8, the most effective inhibitor against transient expression of NRADD (Figure 7a, 3c).

Since the $\triangle E C D$ mutant lacks the $\mathrm{N}$-terminal domain that is important for localization, we determined its subcellular localization by cotransfection with ER-targeted YFP and a $\triangle E C D-R F P$ fusion protein. The red fluorescence accumulated in a perinuclear punctate pattern that colocalized with the ER marker suggesting that $\triangle E C D$ NRADD is retained in the ER (Figure 7b).

Stable ST14A lines expressing $\triangle E C D$ NRADD in the ecdysone system were established to identify an apoptotic phenotype in cells that expressed NRADD DN (Figure 7c). The cells were subjected to several apoptotic insults in the presence and absence of ponasterone. Addition of ponasterone to these cells causes a moderate level of cytotoxicity compatible with the low level of toxicity observed with $\triangle \mathrm{ECD}$ NRADD in transient assays (Figure 4B). However, in combination with the ER stressors thapsigargin, tunicamycin, and brefeldin $\mathrm{A}$, induction of $\triangle \mathrm{ECD}$ NRADD by ponasterone produced significant protection. Thapsigargin induces cell death by inhibiting the $\mathrm{Ca}^{2+}$-dependent ER ATPase. Tunicamycin is a potent inhibitor of $\mathrm{N}$-glycosylation, and brefeldin $\mathrm{A}$ interferes with vesicle transport between the ER and Golgi. ${ }^{20}$ The protection against ER stress was specific as treatment with TNF- $\alpha$, etoposide, and UV produced more killing in the presence of ponasterone. In addition, the effect size was greater in clones with good induction than in pooled transfectants, which have a lesser degree of inducibility of the dominant negative.

To establish a protective effect in a primary cell of neural origin, Schwann cells were used because they express NRADD (not shown) and are also sensitive to NRADD killing (Figure 2a). Schwann cell transfectants expressing $\triangle \mathrm{ECD}$ NRADD constitutively were selected and subjected to the same treatments as above (Figure 7c). Vector controls were isolated and assayed in parallel. The protection pattern was similar to that observed in ST14A cells. The cytotoxicity of thapsigargin was completely eliminated for the $24 \mathrm{~h}$ duration of the experiment. A high degree of specificity is indicated by the lack of protection against TNF- $\alpha$ and etoposide. Furthermore, Schwann cells were not protected from apoptosis induced by serum withdrawal.

The protective activity of NRADD DN suggests that FLNRADD induces cell death through the ER. The localization of NRADD DN to the ER and FL-NRADD to the cell membrane indicates that the inhibition is not mediated by direct interaction. These experiments do not reveal whether ER stressors activate NRADD directly and do not pinpoint the signaling event that is susceptible to NRADD DN. They imply, however, that additional proteins, such as NRADD, are involved in the already complex response of the ER to stress in higher eucaryotes.

\section{Discussion}

The NRADD protein is a hybrid between a sequence with high homology to the intracellular domain of $p 75^{\mathrm{NTR}}$ and a short 
a

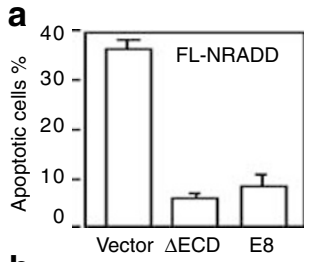

b
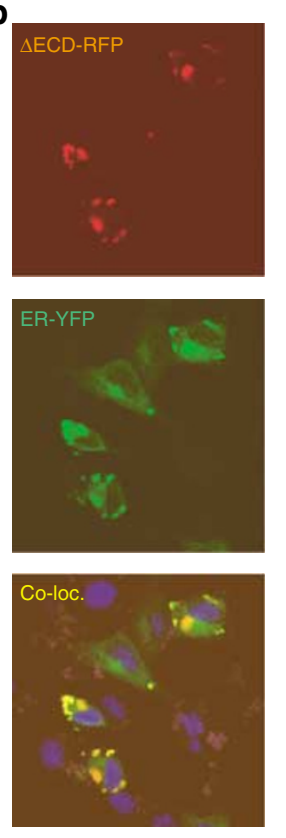
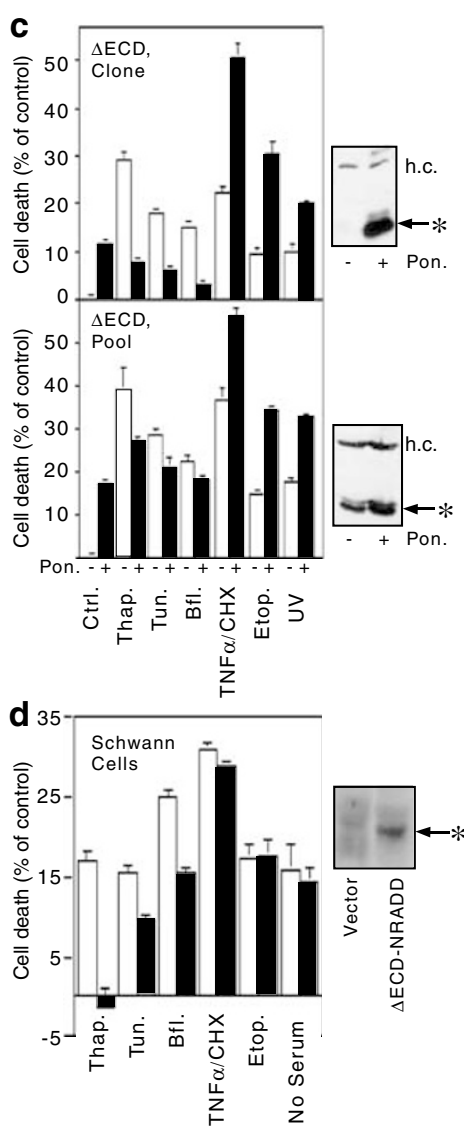

Figure 7 A dominant-negative version of NRADD blocks ER-induced cell death. (a) NRADD-FL ST14A transfectants were cotransfected with GFP vector and the indicated plasmids. After ponasterone treatment for $48 \mathrm{~h}$, cells were scored for apoptotic morphology by fluorescence microscopy. The results are from three experiments $(n=3)$. (b) Subcellular localization of $\triangle$ ECD-RFP in ST14A cells. Cells were fixed $24 \mathrm{~h}$ after transfection and stained with DAPI (blue). Colocalization appears in yellow. (c) A stable ST14A-transfectant expressing $\triangle$ ECD-NRADD-FLAG with the ponasterone inducible system was treated with the indicated reagents for $48 \mathrm{~h}$ in the presence (filled bars) or absence of ponasterone (open bars). Upper panel, a randomly selected single clone, lower panel pooled transfectants. Viability was measured by MTS assay and cell death calculated by comparison with the untreated control. Treatment was as follows: Thap., $0.3 \mu \mathrm{M}$ thapsigargin; Tun., $5 \mu \mathrm{g} / \mathrm{ml}$ tunicamycin; Bfl., $2 \mu \mathrm{g} / \mathrm{ml}$ brefeldin A; TNF $\alpha / \mathrm{CHX}, 100 \mathrm{ng} / \mathrm{ml}$ TNF- $\alpha$ plus $10 \mu \mathrm{M}$ cycloheximide; Etop., $0.1 \mathrm{mM}$ etoposide; UV, $15 \mathrm{~J}$ of UV radiation. The inset shows Western blot analysis of the FLAG-immunoprecipitates from the cell lines used in the experiment with and without ponasterone treatment. $\triangle E C D-N R A D D\left({ }^{*}\right)$, h.c.: heavy chain. (d) A stable Schwann cell transfectant expressing $\triangle E C D-N R A D D$ under the control of the constitutive CMV promoter was analyzed similarly (filled bars) and compared to the vector transfected control (open bars). Serum withdrawal was for $48 \mathrm{~h}$ (-serum). The data are from three independent determinations $(n=3)$

unique $\mathrm{N}$-terminal domain. The cysteine-rich domains that define the TNFR/NGFR superfamily are not part of NRADD. ${ }^{4}$ Therefore, NRADD represents a new class of membrane proteins with a DD. NRADD is a type III transmembrane protein, as it lacks a leader sequence and its $\mathrm{N}$-terminus has the potential to protrude through cellular membranes. Whereas most TNFR/NGFR superfamily members are type I transmembrane proteins, a few such as TACl and XEDAR are targeted to membranes without a leader sequence.

The sequence described here contains 52 additional $\mathrm{N}$ terminal amino acids compared to GeneBank BAB25059, which was identified from a genomic approach to clon FL sequences. ${ }^{21}$ In our longer sequence, the initiator methionine is preceded by an in-frame stop codon and is part of a Kozak consensus sequence. Assembly of ESTs from other vertebrates revealed initiator methionines with the same properties, suggesting that the FL sequence was obtained. In addition, the analysis of ESTs and mRNA revealed multiple isoforms (not shown, and Figure 1). These shorter forms were not investigated here.

Transient expression of NRADD was moderately cytotoxic in a limited number of cell types. NRADD cytotoxicity was drastically enhanced in stable transfectants. NRADD induces cell death by an apoptotic mechanism as indicated by the DNA degradation pattern and activation of caspases. Significant differences exist between the apoptotic mechanisms of NRADD and its homologue $p 75^{\mathrm{NTR}}$. Apoptosis induced by p75 ${ }^{\mathrm{NTR}}$ was also analyzed in the ST14A system facilitating a comparison. ${ }^{7}$ NRADD induces a caspase-8-like activity, while the only apical caspase induced by $\mathrm{p} 75^{\mathrm{NTR}}$ is caspase- 9 . Bcl$x_{L}$ and caspase- $9 D N$, which are potent inhibitors of $p 75^{N T R}$ in multiple systems including ST14A cells, ${ }^{7}$ do not affect apoptosis induced by NRADD. These results are consistent with an NRADD-induced apoptotic pathway that does not require any mitochondrial components. Such a direct pathway of activating caspases has previously only been described for death receptors in type I cells. ${ }^{22}$ NRADD also triggers other signaling pathways such as the activation of AP-1 promoter or p38 kinase. Some of these pathways potentially contribute to the apoptotic activity of NRADD, especially p38, which has been shown to phosphorylate and activate CHOP, a transcription factor that is induced by ER stress. ${ }^{19}$

Mutational analysis indicated that the intracellular signaling of NRADD is different from $p 75^{\mathrm{NTR}}$. The DD of p75 NTR is required to induce apoptosis in ST14A cells. ${ }^{7}$ However, deletion of the DD in NRADD leads to a molecule that retains some of its proapoptotic potential in transient assays. This implies that the membrane proximal sequence is able to activate caspases. The homologous domain of $p 75^{\text {NTR }}$ has been named chopper domain and induces apoptosis in sensory neurons. ${ }^{23}$ Interestingly, the chopper domain is particularly effective in the absence of the extracellular domain of $p 75^{\text {NTR }}$, a construct that closely resembles NRADD except for the signal sequence. Cys 279 of $p 75^{\mathrm{NTR}}$, identified as a necessary residue for chopper activity, is not found in NRADD but it is possible that the nearby Cys76 of NRADD functions analogously. A number of proteins have been reported to interact with the chopper domain of $p 75^{\mathrm{NTR}} \cdot{ }^{24}$ The signaling pathways activated by these $p 75^{\mathrm{NTR}}$ interacting proteins are not yet fully elucidated, and some of the same proteins could also be involved in transducing signals from the highly homologous juxtamembrane domain of NRADD.

We have assayed for homotypic interaction with other DDcontaining proteins and found that other death receptors (p75 NTR, TNFR1, FAS, DR3, 4, 5, 6), and adaptor molecules (FADD, TRADD, RAIDD) did not coimmunoprecipitate with NRADD (data not shown). The lack of homotypic interaction partners is also a property of the DD of p $75^{\mathrm{NTR}}$, suggesting 
that the interactions of these DDs are different from the other death receptors.

The N-terminal domain is important for proapoptotic activity as its deletion causes loss of function and dominant interference with the killing of FL-NRADD. By analogy to other receptors, binding of a ligand to this domain would be the most likely mechanism. Since the short ECD has no homology to an established ligand-binding domain, likely ligands cannot be proposed. However, the mutational analysis is consistent with a ligand binding to the ECD. Furthermore, glycosylation of the ECD is required for maturation of NRADD in the ER. Death receptors are also glycosylated on their extracellular domains, but the functional significance is poorly understood. In contrast to NRADD, studies with $\mathrm{p} 75^{\mathrm{NTR}}$ have shown that $\mathrm{N}$-glycosylation is not required for cell surface expression. ${ }^{25}$ Deletion of the ECD caused NRADD to be retained in the ER, consistent with its role in cellular targeting. Ligand binding and subcellular targeting are not mutually exclusive and the ECD could provide both functionalities. A further indication that the $E C D$ is required but not sufficient to induce apoptosis is the inability of the ECD/TM-GFP construct to kill ST14A cells (not shown). Moreover, levels of NRADD protein were increased by placing a FLAG tag at the N-terminus or by treatment with tunicamycin. Together with the N-terminal proteolytic degradation products observed this may indicate that the ECD also affects protein stability.

Most significantly, NRADD DN retained in the ER interferes with apoptotic stimuli generated by ER stress. A well-understood physiological stimulus of ER stress is the unfolded protein response (UPR). The signaling pathways of the UPR in yeast are well understood, however, in higher eucaryotes the UPR is more sophisticated and is able to respond to a wide variety of stress signals with more diverse downstream effects including induction of apoptosis. The luminal ligand(s) that trigger the ER response have not been fully identified. Several kinases with a domain protruding into the ER lumen have been shown to be involved in protective responses. ${ }^{8}$ ERmediated apoptosis triggers a cascade that leads to the activation of caspase-12. ${ }^{11,26}$ Calpain, caspase-7, and TRAF2 have all been proposed to be part of this cascade. $^{12-14}$ Given the diversity of inducers of ER stress, different cascades may be activated depending on the insult. In ST14A cells, NRADD expression did result in caspase-12 processing. However, further studies are needed to establish whether NRADD interacts with the known components of the ER-mediated cell death pathway or if it functions through other effector pathways. Initial experiments did not reveal any binding of caspase-12 to NRADD in coimmunoprecipitation assays (not shown). Supporting an alternative, caspase-12 independent pathway, is the observation that NRADD activates caspase- 8 and is susceptible to VFLIP inhibition. Such a pathway could involve Bap31, an ER protein that has been shown to associate with caspase- 8 and is involved in transmitting apoptotic signals. ${ }^{27}$

The ER stress response is not only activated by pharmacological agents, but has also been implicated in several disease states in which mutated proteins are retained in the ER. ${ }^{28}$ For example, the $\beta$-amyloid precursor protein (APP) is processed in the ER to yield the two peptides $A \beta 42$ and $A \beta 40$. The ER apoptotic pathway is implicated by the observation that cortical neurons from caspase-12 -/- mice are protected from $A \beta$ induced cytotoxicity. ${ }^{11}$ Some reports have suggested that the UPR response is deficient in cells expressing diseasecausing presenilin mutants. ${ }^{29}$ These observations have been challenged and novel mechanisms that are distinct from the classical UPR pathway have been postulated. ${ }^{30}$ However, it is unclear how the proapoptotic signal is generated. A molecule like NRADD could generate this signal particularly if it is activatable by amyloid peptides. Further investigations of the interplay between the multiple ER responses and NRADD are needed to uncover the potential role of NRADD in pathological responses to cellular stress.

\section{Materials and Methods}

\section{Reagents and antibodies}

Zeocin and ponasterone were from Invitrogen (Carlsbad, CA, USA), Hygromycin B from Roche (Indianapolis, IN, USA). Lipofectin and lipofectamine 2000 were from GIBCO BRL (Gathersburg, MD, USA). MTS kit was from Promega (Madison, WI, USA). Caspase substrates were from Stratagene (La Jolla, CA, USA). DNAzol was from Molecular Research Center, Inc. (Cincinnati, OH, USA). PNGase $F$ reagents were from Prozyme (San Leandro, CA, USA). DNA sequencing and oligonucleotide synthesis services were from the University of Michigan core facilities. PI, poly-L-lysine hydro bromide, and $\alpha$-FLAG M2 antibody were from Sigma (St Louis, MO, USA). $\alpha$-GFP, pGFP, and pDsRed2 vectors were from Clontech Laboratories, Inc (Palo Alto, CA, USA). DiD stain was from Molecular Probes (Eugene, OR, USA). $\alpha$-Myc antibodies were from BABCO (Richmond, CA, USA). Secondary antibodies and ECL reagents were from Amersham Life Science (Piscataway, NJ, USA).

\section{Cell lines}

ST14A, a conditionally immortalized cell line from the rat striatum, ${ }^{31}$ SHEP and SH-SY5Y, human neuroblastoma cell lines, PC12 cells, a rat pheochromocytoma line, and 293 cells, a human embryonic kidney cell line, were cultured in Dulbecco's modified Eagle's medium (DMEM) medium supplemented with $10 \%$ fetal bovine serum (FBS) $0.1 \mathrm{mM}$ nonessential amino acids, $2 \mathrm{mM} \mathrm{L-glutamine,} \mathrm{and} \mathrm{penicillin/streptomycin}$ in $5 \% \mathrm{CO}_{2}$ at $37^{\circ} \mathrm{C}$. ST14A cells were cultured at $33^{\circ} \mathrm{C}$. The serum for PC12 cells was heat inactivated and supplemented with $5 \%$ horse serum. MCF7 cells, a human breast carcinoma cell line, and HeLa cells, a human cervical carcinoma cell line, were cultured in RPMI 1640 medium supplemented as above. A-431 carcinoma cells were grown in DMEM/F $12(1: 1)$ supplemented as above plus $0.25 \mathrm{mg} / \mathrm{ml}$ amphotericin $B$. Schwann cells were isolated from sciatic nerve of neonatal rats as described previously. ${ }^{32}$ Briefly, a single-cell suspension was obtained by trypsin and collagenase digestion followed by culturing in 10\% FBS, $6 \mathrm{mM}$ L-glutamine, $100 \mathrm{U} / \mathrm{ml}$ penicillin $/ 100 \mu \mathrm{g} / \mathrm{ml}$ streptomycin, $20 \mu \mathrm{g} / \mathrm{ml}$ pituitary extract, and $2 \mu \mathrm{M}$ Forskolin on poly-L-lysine-coated tissue culture dishes at $37^{\circ} \mathrm{C}$.

\section{Expression vectors}

Epitope-tagged expression constructs were made in pcDNA3.1-myc-His-A $(-)$ and pcDNA3.1/zeo vectors (Figure 4A). The GFP and RFP fusion proteins were constructed in $\mathrm{pEGFP}$ and $\mathrm{pDsRed} 2$ vectors, respectively. For inducible expression, the coding region was subcloned into the ecdysone-inducible mammalian expression vector pIND-Hygro (Invitro- 
gen). A human $\mathrm{p} 75^{\mathrm{NTR}}$ plasmid (hp75) was kindly provided by Moses $\mathrm{V}$ Chao (New York University). All constructs were verified by sequencing and expression in 293 cells. AP-1, Gal4-ATF2, Gal4-CHOP plasmids were from Stratagene (La Jolla, CA, USA).

\section{Transfections}

ST14A and MCF7 cells were transfected with lipofectamine, Schwann cells with lipofectamine 2000, SHEP, SH-SY5Y cells by lipofectin, and 293 cells by $\mathrm{CaPO}_{4}$. For stable expression, pIND/Hygro constructs were cotransfected with the ecdysone receptor plasmid pVgRXR and selected with Hygromycin B and zeocin. Stable Schwann cells were obtained by transfection with $\triangle E C D-N R A D D-F L A G$ in pcDNA3.1 and selection with G418. Transfectants were screened for expression by immunoblotting.

\section{Library screening}

The mouse embryo day 14.5 Lambda cDNA library in the Uni-ZAP XR vector system was purchased from Stratagene. The library was screened using the EST AV149215 according to standard protocols. ${ }^{33}$

\section{Northern blot}

Commercially available mouse multiple tissue Northern blots were probed by FL-mNRADD according to the manufacturer's instructions (Clontech, Palo Alto, CA, USA). The blots were also hybridized with a $\beta$-actin cDNA probe. For the cell line Northern blot, total RNA was isolated from ST14A cells using the Trizol reagent (GIBCO), then mRNA was prepared using the Oligotex kit (Qiagen). mRNA ( $3 \mu \mathrm{g}$ ) was loaded on each lane. The blot was hybridized with a ratNRADD cDNA probe and $\beta$-actin.

\section{MTS assay}

About $5 \times 10^{4}$ cells were seeded per well in 96-well plate with $100 \mu \mathrm{l}$ medium, then cells were either treated with ponasterone or left untreated. Combined MTS/PMS $(20 \mu \mathrm{l})$ solution was added to each well, incubated at $37^{\circ} \mathrm{C}$ for $1 \mathrm{~h}$, and absorbance was read at $490 \mathrm{~nm}$.

\section{DNA fragmentation assay}

About $5 \times 10^{6} \mathrm{FL}-\mathrm{NRADD}$ ST14A transfectants treated with ponasterone or left untreated were harvested by DNAzol. The DNA was purified by $\mathrm{EtOH}$ precipitation. The precipitate was dissolved in $\mathrm{H}_{2} \mathrm{O}$, digested 30 min at $37^{\circ} \mathrm{C}$ with $20 \mu \mathrm{g} / \mathrm{ml}$ of DNAse-free RNAse, then analyzed by agarose electrophoresis.

\section{Microscopic determination of cell death}

Cells were grown on gelatin-coated coverslips and cotransfected with GFP as a marker $(0.25 \mu \mathrm{g})$ and NRADD expression constructs $(1 \mu \mathrm{g})$. For experiments with inducible stable transfectants, cells were transfected similarly but, in addition, treated with ponasterone or left untreated after transfection. Cells were washed with PBS and fixed with $4 \%$ paraformaldehyde, incubated for $10 \mathrm{~min}$ in $0.5 \mu \mathrm{g} / \mathrm{ml} \mathrm{PI}$, and washed with PBS. Transfected (green) cells were scored by fluorescence microscopy for a PI staining pattern indicating chromatin condensation and nuclear fragmentation.

\section{Fluorescence microscopy}

ST14A transfectants were cultured on gelatin-coated coverslips. For DiD staining, cells were washed in Optimem media stained with $5 \mu \mathrm{l} / \mathrm{ml}$ DiD in Optimem for $8 \mathrm{~min}$. Cells were washed three times with Optimem for $30 \mathrm{~min}$, the last wash containing DAPI $(10 \mu \mathrm{g} / \mathrm{ml})$. Fixation was in $4 \%$ fresh formaldehyde in media at RT for 10 min followed by two washes in PBS. Confocal microscopy was performed using a Zeiss LSM 510.

\section{FACS analysis}

293 cells were transiently transfected with AU1-FL-FLAG construct. After $24 \mathrm{~h}$, a single cell suspension was prepared, washed in PBS, blocked with $10 \%$ goat serum $5 \%$ BSA in PBS for 30 min, and incubated with $\alpha$-AU1antibody $(1: 100)$ for $10 \mathrm{~min}$. Incubation with FITC-conjugated secondary antibody $(1: 2000)$ was for $1 \mathrm{~h}$. All processing was performed at $4^{\circ} \mathrm{C}$. The cells were analyzed on a Beckman Flow Cytometer.

\section{Caspase activity assays}

Cell extracts and enzyme assays were performed as previously described. ${ }^{7}$ The following tetrapeptide substrates were used: caspase-1like, Ac-YVAD-AFC; caspase-3-like, Ac-DEVD-AFC; caspase-8-like, AcIETD-AFC; caspase-9-like, Ac-LEHD-MCA. Caspase-12 processing was assayed in whole-cell lysates using the $\alpha$-caspase-12 antibody from Junying Yuan (Harvard Medical School, Boston, MA, USA) as described. ${ }^{11}$

\section{In vitro deglycosylation}

FLAG-NRADD was purified form transfected 293 cell by FLAG immunoprecipitation. The beads were resuspended in $135 \mu \mathrm{l}$ of PNGase buffer and $7.5 \mu \mathrm{l}$ of denaturation buffer, heated for $5 \mathrm{~min}$ at $100^{\circ} \mathrm{C}$, cooled to RT and $7.5 \mu$ l Triton X-100 was added. The suspension was split equally and $50 \mathrm{U}$ of PNGase F was added to one aliquot. Incubation was overnight at $37^{\circ} \mathrm{C}$ followed by SDS-PAGE.

\section{Luciferase assay}

Luciferase assay was performed following the manufacturer's instruction (Dual luciferase kit, Promega, Madison, WI, USA) using the renilla plasmid $\mathrm{pRC}-\mathrm{Tk}$ to normalize for transfection efficiency.

\section{Apoptosis induction}

$\triangle$ ECD-NRADD-transfectants (ST14A or Schwann cells) were exposed to one of the following treatments: $0.3 \mu \mathrm{M}$ thapsigargin, $5 \mu \mathrm{g} / \mathrm{ml}$ tunicamycin, $2 \mu \mathrm{g} / \mathrm{ml}$ brefeldin A, $100 \mathrm{ng} / \mathrm{ml}$ TNF- $\alpha$ plus $10 \mu \mathrm{M}$ cycloheximide, $0.1 \mathrm{mM}$ etoposide for $24 \mathrm{~h}$. Where indicated, ST14A cells were treated with $1 \mu \mathrm{M}$ ponasterone during this time period. ST14A transfectants were irradiated with a germicidal UV light $(254 \mathrm{~nm}, 15 \mathrm{~J})$. Following irradiation, the transfectants were supplied with media with or without $1 \mu \mathrm{M}$ ponasterone for $48 \mathrm{~h}$. For serum deprivation, Schwann cells were cultured in $1 \% \mathrm{BSA}$ for $24 \mathrm{~h}$.

\section{Statistical analysis}

StatView software was used to calculate significant differences by ANOVA. $P$-values $<0.05$ were considered significant and are indicated $\left.{ }^{\star}\right)$. Error bars indicate standard errors (S.E.). 


\section{Acknowledgements}

We thank Chris Weber for the sequence alignments. The ST14A cells were generously provided by Elena Cattaneo (University of Milano, Italy). We also thank James Russell for providing Schwann cells, Alnawaz Rehemtulla for ultraviolet radiation, and Yuseef Namy for help in preparing the figures. Junying Yuan generously provided the caspase-12 antibodies (Harvard Medical School). A-431 cells were provided by Yoram Milner (The Hebrew University-Jerusalem, Israel), and PC12 were from Lei Sun (University of Michigan). The work was supported by NIH ES08111 and DAMD 17-96-6085 grants.

\section{Note added in proof}

NRADD has been recently characterized as PLAIDD. ${ }^{34}$

\section{References}

1. Yuan J, Shaham S, Ledoux S, Ellis HM and Horvitz HR (1993) The C. elegans cell death gene ced-3 encodes a protein similar to mammalian interleukin-1 $\beta$-converting enzyme. Cell 75: 641-652

2. Weber $\mathrm{CH}$ and Vincenz $\mathrm{C}$ (2001) The death domain superfamily: a tale of two interfaces? Trends Biochem. Sci. 26: 475-481

3. Martinon F, Hofmanndouble dagger $K$ and Tschopp J (2001) The pyrin domain: a possible member of the death domain-fold family implicated in apoptosis and inflammation. Curr. Biol. 11: R118-R120

4. Locksley RM, Killeen N and Lenardo MJ (2001) The TNF and TNF receptor superfamilies: integrating mammalian biology. Cell 104: 487-501

5. Lee FS, Kim AH, Khursigara G and Chao MV (2001) The uniqueness of being a neurotrophin receptor. Curr. Opin. Neurobiol. 11: 281-286

6. Lee R, Kermani P, Teng KK and Hempstead BL (2001) Regulation of cell survival by secreted proneurotrophins. Science 294: 1945-1948

7. Wang X, Bauer JH, Li Y, Shao Z, Zetoune FS, Cattaneo E and Vincenz C (2001) Characterization of a p75NTR apoptotic signaling pathway using a novel cellular system. J. Biol. Chem. 276: 33812-33820

8. Kaufman RJ (1999) Stress signaling from the lumen of the endoplasmic reticulum: coordination of gene transcriptional and translational controls. Genes Dev. 13: 1211-1233

9. Bertolotti A, Zhang Y, Hendershot LM, Harding HP and Ron D (2000) Dynamic interaction of $\mathrm{BiP}$ and $\mathrm{ER}$ stress transducers in the unfolded-protein response. Nat. Cell. Biol. 2: 326-332

10. Urano F, Wang X, Bertolotti A, Zhang Y, Chung P, Harding HP and Ron D (2000) Coupling of stress in the ER to activation of JNK protein kinases by transmembrane protein kinase IRE1. Science 287: 664-666

11. Nakagawa T, Zhu H, Morishima N, Li E, Xu J, Yankner BA and Yuan J (2000) Caspase-12 mediates endoplasmic-reticulum-specific apoptosis and cytotoxicity by amyloid-beta. Nature 403: 98-103

12. Nakagawa $T$ and Yuan J (2000) Cross-talk between two cysteine protease families. Activation of caspase-12 by calpain in apoptosis. J. Cell. Biol. 150: 887-894

13. Yoneda T, Imaizumi K, Oono K, Yui D, Gomi F, Katayama T and Tohyama M (2001) Activation of caspase-12, an endoplasmic reticulum (ER) resident caspase, through tumor necrosis factor receptor-associated factor 2- dependent mechanism in response to the ER stress. J. Biol. Chem. 276 $13935-13940$

14. Rao RV, Hermel E, Castro-Obregon S, del Rio G, Ellerby LM, Ellerby HM and Bredesen DE (2001) Coupling endoplasmic reticulum stress to the cell death program: mechanism of caspase activation. J. Biol. Chem. 276: 3386933874

15. Zinszner H, Kuroda M, Wang X, Batchvarova N, Lightfoot RT, Remotti H, Stevens JL and Ron D (1998) CHOP is implicated in programmed cell death in response to impaired function of the endoplasmic reticulum. Genes Dev. 12 982-995

16. Majdan M, Lachance C, Gloster A, Aloyz R, Zeindler C, Bamji S, Bhakar A, Belliveau D, Fawcett J, Miller FD and Barker PA (1997) Transgenic mice expressing the intracellular domain of the p75 neurotrophin receptor undergo neuronal apoptosis. J. Neurosci. 17: 6988-6998

17. von Heijne $G$ and Gavel $Y$ (1988) Topogenic signals in integral membrane proteins. Eur. J. Biochem. 174: 671-678

18. Parodi AJ (2000) Role of $\mathrm{N}$-oligosaccharide endoplasmic reticulum processing reactions in glycoprotein folding and degradation. Biochem. J. 348(Part 1): $1-13$

19. Wang XZ and Ron D (1996) Stress-induced phosphorylation and activation of the transcription factor CHOP (GADD153) by p38 MAP Kinase. Science 272: 1347-1349

20. Kozutsumi Y, Segal M, Normington K, Gething MJ and Sambrook J (1988) The presence of malfolded proteins in the endoplasmic reticulum signals the induction of glucose-regulated proteins. Nature 332: 462-464

21. Kawai J, Shinagawa A, Shibata K, Yoshino M, Itoh M, Ishii Y, Arakawa T, Hara A, Fukunishi Y, Konno H, Adachi J, Fukuda S, Aizawa K, Izawa M, Nishi K, Kiyosawa H, Kondo S, Yamanaka I, Saito T, Okazaki Y, Gojobori T, Bono H, Kasukawa T, Saito R, Kadota K, Matsuda HA, Ashburner M, Batalov S, Casavant T, Fleischmann W, Gaasterland T, Gissi C, King B, Kochiwa H, Kuehl P, Lewis S, Matsuo Y, Nikaido I, Pesole G, Quackenbush J, Schriml LM, Staubli F, Suzuki R, Tomita M, Wagner L, Washio T, Sakai K, Okido T, Furuno M, Aono H, Baldarelli R, Barsh G, Blake J, Boffelli D, Bojunga N, Carninci P, de Bonaldo MF, Brownstein MJ, Bult C, Fletcher C, Fujita M, Gariboldi M, Gustincich S, Hill $D$, Hofmann M, Hume DA, Kamiya M, Lee NH, Lyons $P$, Marchionni L, Mashima J, Mazzarelli J, Mombaerts P, Nordone P, Ring B, Ringwald M, Rodriguez I, Sakamoto N, Sasaki H, Sato K, Schonbach C, Seya T, Shibata Y, Storch KF, Suzuki H, Toyo-oka K, Wang KH, Weitz C, Whittaker C, Wilming L, Wynshaw-Boris A, Yoshida K, Hasegawa $\mathrm{Y}$, Kawaji $\mathrm{H}$, Kohtsuki $\mathrm{S}$ and Hayashizaki Y, (2001) Functional annotation of a full-length mouse cDNA collection. Nature 409: 685-690

22. Scaffidi C, Fulda S, Srinivasan A, Friesen C, Li F, Tomaselli KJ, Debatin KM, Krammer PH and Peter ME (1998) Two CD95 (APO-1/Fas) signaling pathways. EMBO J. 17: 1675-1687

23. Coulson EJ, Reid K, Baca M, Shipham KA, Hulett SM, Kilpatrick TJ and Bartlett PF (2000) Chopper, a new death domain of the p75 neurotrophin receptor that mediates rapid neuronal cell death. J. Biol. Chem. 275: 30537-30545

24. Hempstead BL (2002) The many faces of p75NTR. Curr. Opin. Neurobiol. 12: 260-267

25. Baldwin AN and Shooter EM (1995) Zone mapping of the binding domain of the rat low affinity nerve growth factor receptor by the introduction of novel $\mathrm{N}$ glycosylation sites. J. Biol. Chem. 270: 4594-4602

26. Rao RV, Castro-Obregon S, Frankowski H, Schuler M, Stoka V, del Rio G, Bredesen DE and Ellerby HM (2002) Coupling endoplasmic reticulum stress to the cell death program: an Apaf-1-independent intrinsic pathway. J. Biol. Chem. 27: 27

27. Nguyen M, Breckenridge DG, Ducret A and Shore GC (2000) Caspaseresistant BAP31 inhibits fas-mediated apoptotic membrane fragmentation and release of cytochrome $c$ from mitochondria. Mol. Cell. Biol. 20: 6731-6740

28. Thomas PJ, Qu BH and Pedersen PL (1995) Defective protein folding as a basis of human disease. Trends Biochem. Sci. 20: 456-459

29. Imaizumi K, Miyoshi K, Katayama T, Yoneda T, Taniguchi M, Kudo T and Tohyama M (2001) The unfolded protein response and Alzheimer's disease. Biochim. Biophys. Acta. 1536: 85-96

30. Sato N, Urano F, Yoon Leem J, Kim SH, Li M, Donoviel D, Bernstein A, Lee AS, Ron D, Veselits ML, Sisodia SS and Thinakaran G, (2000) Upregulation of BiP and $\mathrm{CHOP}$ by the unfolded-protein response is independent of presenilin expression. Nat. Cell. Biol. 2: 863-870

31. Cattaneo E, Magrassi L, Butti G, Santi L, Giavazzi A and Pezzotta S (1994) A short term analysis of the behaviour of conditionally immortalized neuronal progenitors and primary neuroepithelial cells implanted into the fetal rat brain. Brain Res. Dev. Brain. Res. 83: 197-208

32. Brockes JP, Fields KL and Raff MC. (1979) Studies on cultured rat Schwann cells. I. Establishment of purified populations from cultures of peripheral nerve. Brain Res. 165: 105-118

33. Ausubel FM, Brent R, Kingston RE, Moore DD, Seidman JG, Smith JA and Struhl K (eds.) (1999) Current Protocols in Molecular Biology. New York: John Wiley \& Sons, Inc.

34. Frankowski H, Castro-Obregon S, del Rio G., Rao RV and Bredesen DE (2002) PLAIDD, a type II death domain protein that interacts with p75 neurotrophin receptor. Neuro. Med. 1: 153-170 